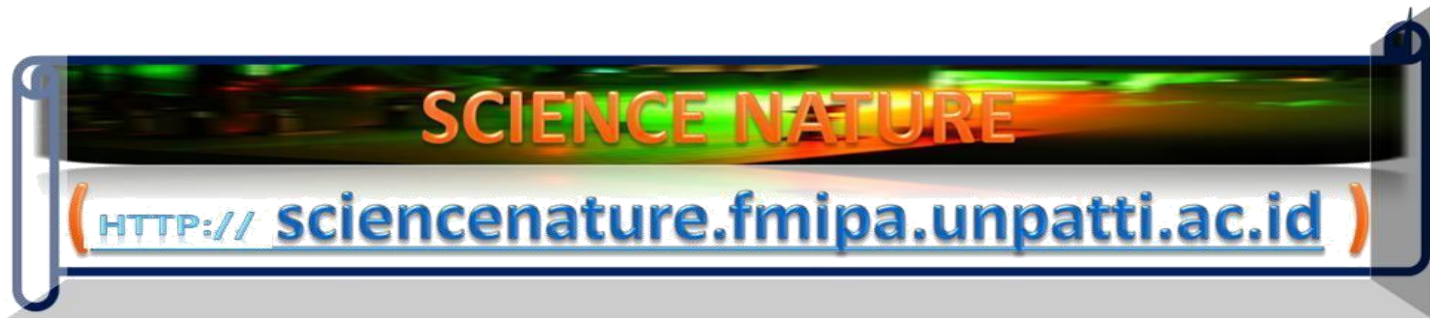

Science Nature 1(1), pp.015-021 (2018)

e-ISSN 2654-6264

DOI: https://doi.org/10.30598/SNVol1Iss1pp015-021year2018

\title{
The Sensory Characteristic of Caulerpa Jelly Candy Based on The Consumers Acceptance
}

\author{
Alfonsina Marthina Tapotubun ${ }^{1 *}$, Th.E.A.A.Matrutty ${ }^{1}$, Elizabeth Juleny Tapotubun ${ }^{2}$, \\ Meigy Nelce Mailoa ${ }^{1}$, and Eirene G. Fransina ${ }^{3}$ \\ ${ }^{1}$ Departement of Technology Fisheries, Faculty of Fisheries and Marine Science, Pattimura University. \\ Jl. Mr. Chr. Soplanit No. 1 - Poka, Ambon, Indonesia 97233. Telepon (0911) 3825060; faks. (0911) 3825061 \\ ${ }^{2}$ Departement of Technology Fisheries, Fisheries Polytechnic of Tual City. Jl. Sathean KM 6, Kecamatan Kei Kecil, Indonesia \\ ${ }^{3}$ Departement of Chemistry, Faculty of Mathematics and Natural Science, Patimura \\ University Jl. Ir. M. Putuhena, Poka, Ambon, Indonesia 97233
}

Received : August 2, 2018

Revised : August 17, 2018

Published : August 21, 2018

Copyright @ All rights are reserved by Alfonsina Marthina Tapotubun

Corresponding author: *Email: am.tapotubun@gmail.com; am.tapotubun@fpik.unpatti.ac.id 
Abstract

To know sensory characteristic of jelly candy based on consumers acceptances. This research used trial method, with ratio between Caulerpa sp and sugar were 1:0.5, 1:1 and 1:1.5. Result of consumer acceptances tests toward color, taste, texture and odor of Caulerpa jelly candy was collected using hedonic range. Caulerpa seaweed could be processed to be jelly candy with consumer acceptance level in range "neutral" to "like". The highest level of consumer acceptance was on the Caulerpa ratio 1:1.5 with acceptance level for color, odor and texture were "not much like", meanwhile acceptance level for taste was "like"

Keywords : seaweed, Caulerpa, consumer acceptance, sensory characteristic

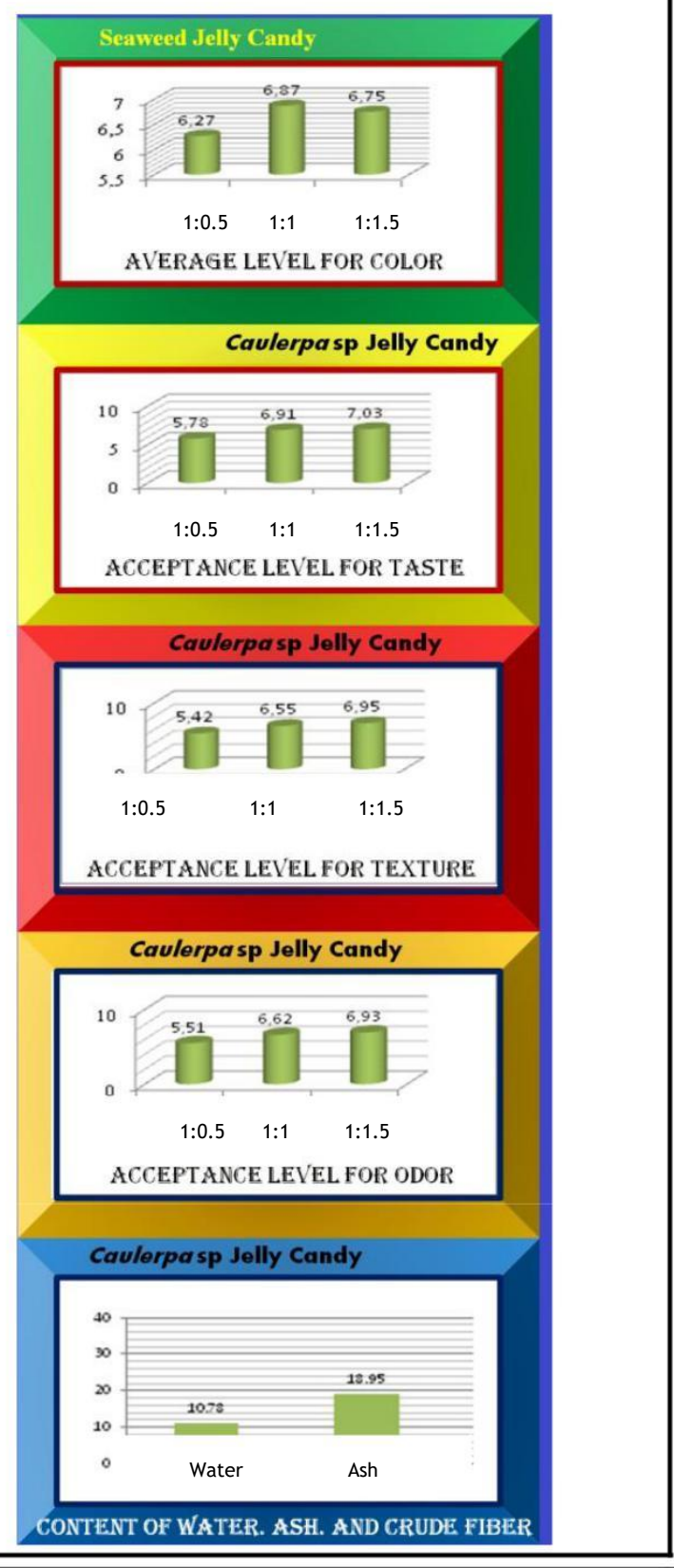

Articles

\section{Introduction}

Seaweed is a kind of green algae genus Caulerpa that lives in shallow, clean and enough lighted water.
Seaweed is one of endemic species in Maluku which known as "Caulerpa sp". Caulerpa sp grows in seaboard area of Kei Islands (Maluku Tenggara Regency) and can be found all year around [1-4]. Couple names of this 
Caulerpa sp are rumput laut or Caulerpa sp (Indonesia), umi budo (Japan), green caviar (Europe), ar-arosep or lato (Philippine) and sea grape as its international name [5].

Jelly candy is one kind of snack product in flexible shape and be fave by all ages mostly children and teenagers for its special characters. The special things of this jelly candy are is its taste, shape, flexibility and elasticity texture. Jelly candy's processing steps are easy and simple using fruit and vegetable extracts, sugar and gel maker ingredient. Jelly candy has clear and transparent out-looking, certain texture and elasticity [6].

Jelly candy is children and teenager's kind of favorite snack. All this time, jelly candy is only processed from some kind of seaweeds, like Eucheuma cotonnii jelly candy [7], Sargassum sp jelly candy [8], Gracilaria sp jelly candy $[\mathbf{8 , 9}]$, seaweed-aloe vera mixed jelly candy [10], etc. Jelly candy processing with those kind of seaweeds above as its main ingredient don't have special taste and odor, so that fruit or vegetable extract or other essence need to be added more to create certain taste and odor, and also need long time process for drying and submersion.

Based on literature study, processing Caulerpa sp seaweed to be jelly candy hasn't been tried yet, so that some research to understand its potential as the main ingredient of jelly candy need to be done. The research is head to know the best ratio between seaweed (Caulerpa sp) and sugar to create jelly candy without any preservative.

\section{Experimental Methods and Techniques}

\subsection{Ingredients}

This research used some ingredients: seaweed (Caulerpa sp), Swallow jelly and sugar (sugar cane). Some tools were also used, such as washbasin, scales, blender, pan, and stove.

\subsection{Methods}

Trial method was used in this research. The trial was purposed to some ratios between seaweed (Caulerpa $\mathrm{sp}$ ) and sugar to create jelly candy without preservatives using simple technology. The ratio of "Caulerpa sp" and sugar $(\mathrm{b} / \mathrm{b})$ were $1: 0.5,1: 1$, and $1: 1.5$, triple tries for each.

\subsection{Procedures}

Seaweed was washed clean with flow water, then was leaked. Seaweed and sugar were scaled based on certain trial and blended using blender. Next step, the admixture was put into a pan, added some jelly and cooked for 10-15 minutes while mixed continuously. Poured the cooked admixture into aluminum mold and leave until chilly, then cut in square shape. Dried it for approximately 8 hours (smeared with tapioca and sugar if wasn't in pack).

\subsection{Consumers acceptances tests}

Consumers acceptances tests toward color, taste, texture and odor of Caulerpa jelly candy from 15 consumers was collected using hedonic range between 9 to 1, which highest score (9) mean so much like and lowest score (1) mean so much dislike [11]. The panelists who conducted organoleptic testing were 15 semi-trained panelists who were students of Fisheries Technology Study Program Pattimura University. The best jelly candy product according to consumers acceptances was analyzed its content of water, ash and crude fiber.

\subsection{Water content}

Water content analysis followed AOAC [12]. Started by drying the porcelain cup at $105^{\circ} \mathrm{C}$ for 1 hour, the cup was put in a desiccator for about 15 minutes and left to dry, then weighed. It was reweighed up to constant weight was obtained, and $5 \mathrm{~g}$ of sample was put and dried in the oven at $105^{\circ} \mathrm{C}$ for 5 hours. Afterwards, the cup was inserted into a desiccator and left to cool, then reweighed. 
Weight loss $(\mathrm{g})=$ initial weight of sample $(\mathrm{g})$ - weight after dried $(\mathrm{g})$

Water content $(\mathrm{w} / \mathrm{w})=\frac{\text { weight loss }(\mathrm{g})}{\text { initial sample weight }(\mathrm{g})} \times 100 \%$

\subsection{Ash}

Blasting cup was dried in an oven at $105^{\circ} \mathrm{C}$ for 1 hour then cooled for 15 minutes in a desiccator and weighted up to constant weight obtained. Sample of $5 \mathrm{~g}$ was put in blasting and blazed over the Bunsen fire up to having no smoke. The cup was then inserted into blast furnace at $400^{\circ} \mathrm{C}$ for 1 hour and weighed up to constant weight gained [12].

Ash weight $(\mathrm{g})=$ final weight of sample and cup $(\mathrm{g})$ - empty cup $(\mathrm{g})$

$\%$ ash content $=[$ ash weight $(\mathrm{g}) /$ sample weight $(\mathrm{g})] \times 100 \%$

\subsection{Data Analysis}

Result of consumer acceptances tests toward color, taste, texture and odor of Caulerpa jelly candy, also water content, ash and crude fiber for the best jelly candy product according to consumer acceptances was analyzed using Microsoft office Excel (Microsoft Inc., USA).

\section{Results and Discussion}

Food processing technology is purposed to change some ingredient food to be some new processed food product which is more interesting, more lovable and more durable, so that its distribution and sale area could be wider. Hence, the processed food product can be consumed not only in long period but also can be distributed to places that more far than its production area.

\subsection{Consumers Acceptance of Jelly Candy}

\subsubsection{Color}

Hedonic test's result showed acceptance level of consumers was on range score 5.3 to 7.3 which similar with level of neutral to like. The result of consumer acceptance level test for color of Caulerpa jelly candy show in Fig. 1.

Color of processed seaweed jelly candy is greenclear. More seaweed will produce more green-colored jelly candy. Green color of jelly candy comes from seaweed chlorophyll. It is different from green-colored jelly candy in Fitrina's research [10] that came from Кири-Кири (butterfly) green food dye.

This research showed that averaged consumers more like the color of jelly candy from ratio seaweed : sugar (1:1) (Fig. 1). The average of consumer acceptance in this test showed like level to all produced green colored seaweed jelly candy. Tapotubun [13] explained that processed sea-grape products have specific green color which comes from Caulerpa nature color itself and also have crystal-clear effect.

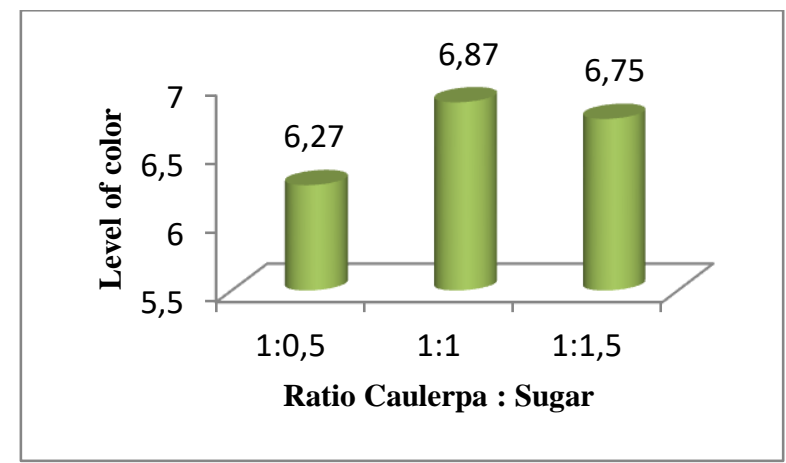

Figure 1. Consumer Acceptance Average Level for Color of Caulerpa Jelly Candy

\subsubsection{Taste}

The sensory characteristic test for taste showed a consumers acceptance level was on range 4.3 (little bit dislike) to 7.7 (like) (Fig. 2). The "like" level for taste of seaweed jelly candy was equal to consumers acceptance level of Eucheuma cottonii jelly candy $[\mathbf{1 4 , 1 5}]$.But it was 
better than the consumers acceptance level of Gracillaria sp and Sargassum sp jelly candy, which were on "little bit like" level [8].

Seaweed jelly candy has mixed taste of sweet and salty. The sweet taste comes from sugar and the salty one comes from nature taste of seaweed itself. Tapotubun [13] explained that processed sea-grape products have salty fresh taste which comes from Caulerpa sp nature taste. The result of this research showed that average consumers were prefer to the taste from Caulerpa sp jelly candy with ratio Caulerpa : sugar ratio 1:1.5 (Fig. 2).

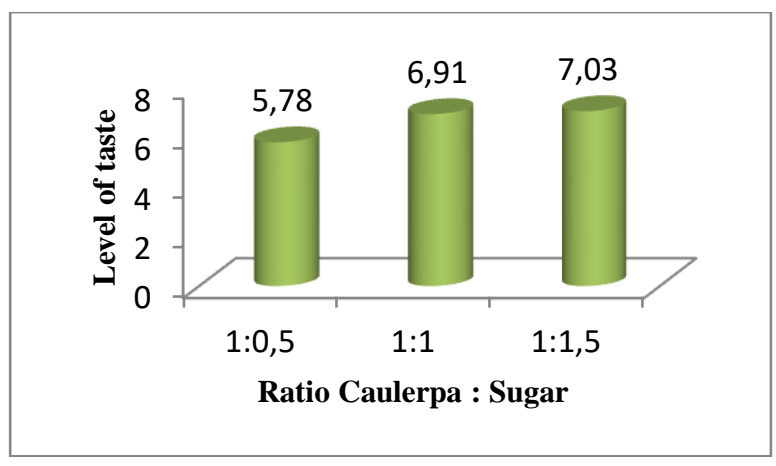

Figure 2. Consumers Acceptance Level for Taste of Caulerpa Jelly Candy

Based on the result, we know if averaged consumers were prefer to the taste of Caulerpa sp jelly candy with ratio seaweed and sugar $1: 1.5$. Ratio of more sugar added will produce a sweeter jelly candy. It is because of the quantity of seaweed was less than sugar. so that the taste of jelly candy in this ratio became sweeter and less salty than jelly candy in other ratios. One of sensory aspect that could influence the consumer acceptance of food is taste. Generally, the taste can be differed as salty, sweet, bitter and sour [14]. Sugar or sucrose is a kind of carbohydrate. Taste sweet. Soluble on water and also could be a food preservative.

\subsubsection{Texture}

The sensory characteristic test for texture of seaweed jelly candy showed a consumers level was on range 4.3 to 7.3 , which was on level "little bit dislike" to "like" (Fig. 3).

Processed seaweed jelly candy has a solid Elastic, Fragile and rough texture. The rough texture comes from incomplete blended sugar. This research showed that consumers were prefer to the product from ratio seaweed : sugar 1:1.5. Despite so. Average level of consumers acceptance in this test showed "little bit like" to the product from ratio $1: 1$ and 1:1.5. Meanwhile average consumers choose level "neutral" to the product from ratio $1: 0.5$.

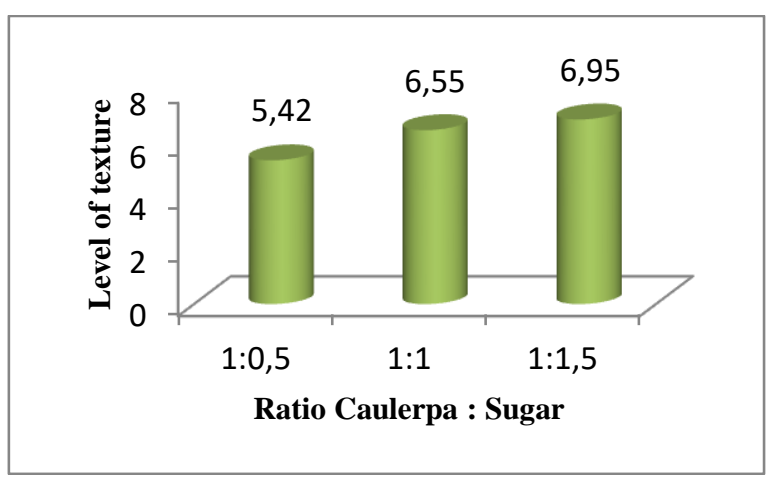

Figure 3. Consumers Acceptance Level for Texture of Caulerpa Jelly Candy

A solid and elastic texture of seaweed jelly candy comes from nature gelatin strength of seaweed itself. The more seaweed added, the more solid and elastic texture of produced jelly candy.

Marwita [15] explained that bigger concentration of seaweed would give stronger texture of product. Gelatin strength of Caulerpa sp. which comes from seaboard area of Kei Islands is $8.00 \mathrm{gr} / \mathrm{cm}^{2}$ [13]. Seaweed contains carrageenan that can increase elasticity of the jelly candy [16].

\subsubsection{Odor}

The sensory characteristic test for odor of seaweed jelly candy showed a consumers level was on range 4.3 to 7.7 which was on level "little bit dislike" to "like". 
Odor produced from seaweed jelly candy comes from a special fresh odor of seaweed mixed with a sweet odor of sugar. The more seaweed added, the ocean odor of jelly candy will be stronger. The consumers were prefer to the product from ratio 200 grams seaweed : 300 grams sugar (1:1.5) (Fig. 4). Despite, the average level of consumers acceptance in this test showed "little bit like" to the products from ratio $1: 1$ and 1:1.5. While average consumers choose level "neutral" to the product from ratio 1: 0.5.

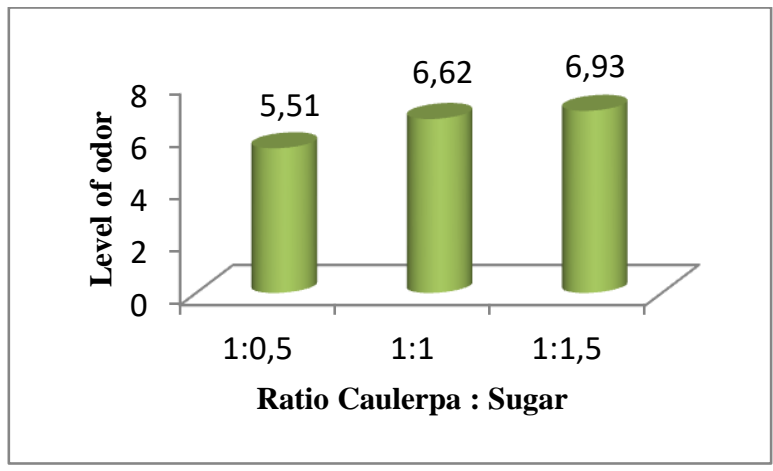

Figure 4. Consumers Acceptance Level for Odor of Caulerpa Jelly Candy

\subsubsection{Content of Water, Ash and Crude Fiber}

Analysis of water. minerals and coarse fiber was done to the Caulerpa sp jelly candy with best consumers acceptance level. which was the product from ratio Caulerpa sp:sugar 1:1.5. Based on the result in Picture 5 seaweed jelly candy had a quite low water amount. which was $18.95 \%$. It was because the candy had been dried in the sun approximately 8 hours after cut. so that most water content had evaporated. The water content is influential to food quality. so that it usually decreased by evaporating or drying [16].

Ash content of seaweed jelly candy in this research was $10.78 \%$. The high quantity came from seaweed. Swallow jelly powder and sugar added. Ash content of fresh seaweed is 3.97\% [13]. Santoso [17] reported that ash content of jelly candy increased as much as seaweed added. Component of ash is minerals Caulerpa from Kei Island for macro minerals is $\mathrm{Mg}, \mathrm{K}, \mathrm{Ca}, \mathrm{Na}$, and micro minerals is $\mathrm{Zn}, \mathrm{Mn}$ and Fe [4].
This result showed high quantity crude fiber compared to product with aloe vera. which had quantity $0.99 \%-1.5 \%$ [10]. The crude fiber contains in this jelly candy was mainly from seaweed and Swallow jelly powder. Fresh seaweed contains $0.002 \%$ crude fiber [13].

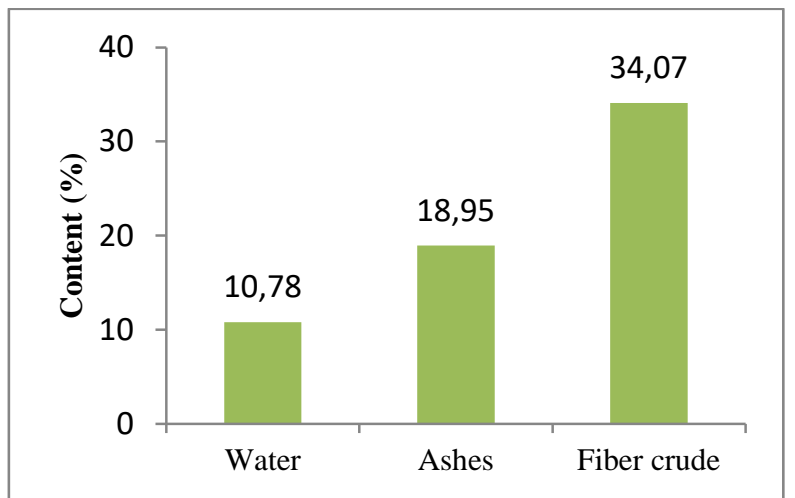

Figure 5. Content of Water. Ash. and crude fiber in Caulerpa Jelly Candy

Crude fiber is a non-sugar food crude fiber. which also is indigestible carbohydrate. Fiber plays role in digestive process and is effective to lowering blood cholesterol [6].

\section{Conclusion}

Consumers acceptance level of Caulerpa sp jelly candy was "neutral" to "like". The highest level was on product from ratio seaweed (Caulerpa sp) 1:1.5 with consumer acceptance for color, odor and texture were "little bit like" and "like". The content of water, ash and coarse fiber in product using ratio 1 for seaweed : 1.5 for sugar were each $18.95 \%, 10.78 \%$, and $34.07 \%$.

\section{Acknowledgements}

Thanks to a government of Republic of Indonesia through the Ministry of Research, Technology and Higher Edications. Directorate of Research and Community Services on PSN-Institusi funds for the implementation of this study. 


\section{References}

[1] A. M. Tapotubun, I.K.E. Savitri, Th.E.A.A. Matrutty, 2016. "The Inhibitor Pathogen Bacteria's of Sea Grape Caulerpa lentillifera Applies on Fresh Fish". J.

Pengolahan Hasil Perikanan Indonesia. 19(3): 299-308. DOI: http://dx.doi.org/10.17844/jphpi.v19i3.15098.

[2] A. M. Tapotubun and I.K.E. Savitri, 2016. "Growth Inhibition of Pathogenic Bacteria on Fresh Fish by Using Dried Seaweed Caulerpa lentillifera During Storage", International Proceeding of $1^{\text {st }}$ The International Conference on Marine Biodiversity, p.114-117. ISBN.: 978-602-294-150-7.

[3] M. N. Mailoa, A.M. Tapotubun, Th.E.A.A. Matruty, 2017. "Analysis Total Plate Counte (TPC) on Fresh Steak Tuna Applications Edible Coating Caulerpa sp During Stored at Chilling Temperature". IOP Conf. Ser.: Earth Environ. Sci. 89:012014.

[4] A. M. Tapotubun, 2018. "Chemical Composition of Sea Grapes Caulerpa lentillifera from Kei Islands Maluku with Different Drying Methods". Jurnal Pengolahan Hasil Perikanan Indonesia.21(1): 13-23. DOI: http://dx.doi.org/10.17844/jphpi.v21i1.21257

[5] Dawes and J. Clinton (1998). "Marine Botany". New York: John Wiley. ISBN 0-471-19208-2.

[6] H. I. Yani, 2006. "Karakteristik Fisika Kimia Permen Jelly dari Rumput Laut Eucheuma spinosum dan Eucheuma cottonii'. Skripsi. Institut Pertanian Bogor.

[7] M. Novitasari, Mappiratu, D. Sulistiawati,. 2016. "Mutu kimia dan organoleptik permen jelly rumput laut gelatin sapi”. e-Jurnal Mitra Sains. 4 (3): 16-21.

[8] A. Yuniarti. 2011. "Kadar Zat Besi, Serat, Gula Total, dan Daya Terima Permen Jelly dengan Penambahan Rumput Laut Gracilaria sp dan Sargassum sp". Artikel Penelitian. Progam Studi Ilmu Gizi Fakultas Kedokteran Universitas Diponegoro, Semarang.
[9] E. Salamah, A.C. Erungan, Yuni. 2006. "Pemanfaatan Gracilariasp dalam Pembuatan Permen Jelly”. Buletin Teknologi Hasil Pertanian. 9(1): 38-46.

[10] F. Fitrina, A. Ali, S. Fitriani, 2014. "'Rasio Lidah Buaya dan Rumput Laut Terhadap Mutu Permen Jelly". Jurnal Sagu. 13(1): 14-21.

[11] S.T. Soekarto, 1990. "Penilaian Organoleptik Untuk Industri Pangan dan Hasil Pertanian". Jakarta: Bhatara Aksara.

[12] [AOAC] Association of Official Analytical Chemist, 2005. "Official Methods of Analysis of the Association of Official Analytical Chemist". 18th ed. AOAC (Washington DC - USA). Method 935.14 and 992.24.

[13] A. M. Tapotubun, 2016. Lat (Caulerpa sp). Rumput Laut Khas Maluku; Inventarisasi Potensi dan

Pemanfaatannya. Proseding Seminar Nasional Masyarakat Pengolahan Hasil Perikanan Indonesia dan Pertemuan Ilmiah VIII: 344-351.

[14] F. G. Winarno. 2002. Kimia Pangan dan Gizi. PT. Gramedia. Jakarta.

[15] Marwita. R. 2008. Penerimaan Konsumen dan Mutu Permen Jelly yang Diolah dari Rumput Laut. Skripsi. Teknologi Hasil Perikanan. Fakultas Perikanan. Universitas Riau. Pekan baru.

[16] F. G. Winarno, 1996. “Teknologi Pengolahan Rumput Laut”. Gramedia Pustaka Utama. Jakarta.

[17] Santoso, D. 2007. "Pemanfaatan Rumput Laut Gellidium $s p$. dalam Pembuatan Permen Jelly". Skripsi. Program Studi Teknologi Hasil Perikanan. Fakultas Pertanian. Institut Pertanian Bogor (Tidak Dipublikasikan).

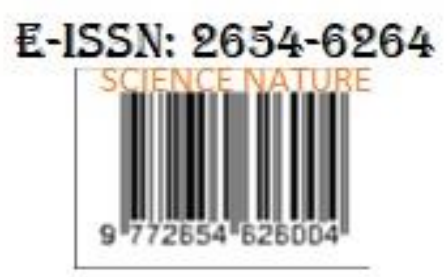

